\title{
Fuhrman Nuclear Grade
}

National Cancer Institute

\section{Source}

National Cancer Institute. Fuhrman Nuclear Grade. NCI Thesaurus. Code C62411.

A 4-point scale for renal cell carcinoma that indicates the level of protein synthesis activity in malignant cells based on the appearance of the nuclei. The grading ranges from I (best prognosis) to IV (worst prognosis). 